\title{
ERK1 is dispensable for mouse pancreatic beta cell function but is necessary for glucose-induced full activation of MSK1 and CREB
}

\author{
Michele Leduc $^{1}$ - Joy Richard ${ }^{1} \cdot$ Safia Costes ${ }^{1} \cdot$ Dany Muller $^{1} \cdot$ Annie Varrault ${ }^{1}$. \\ Vincent Compan $^{1}$ - Julia Mathieu ${ }^{1}$. Jean-François Tanti ${ }^{2} \cdot$ Gilles Pagès $^{3}$ • \\ Jacques Pouyssegur $^{3,4}$ - Gyslaine Bertrand ${ }^{1} \cdot$ Stéphane Dalle $^{1}$ - Magalie A. Ravier ${ }^{1}$
}

Received: 25 January 2017 / Accepted: 2 June 2017 / Published online: 18 July 2017

(C) Springer-Verlag GmbH Germany 2017

\begin{abstract}
Aims/hypothesis Insufficient insulin secretion from pancreatic beta cells, which is associated with a decrease in beta cell mass, is a characteristic of type 2 diabetes. Extracellular signal-related kinase 1 and 2 (ERK1/2) inhibition in beta cells has been reported to affect insulin secretion, gene transcription and survival, although whether ERK1 and ERK2 play distinct roles is unknown. The aim of this study was to assess the individual roles of ERK1 and ERK2 in beta cells using ERK1 (also known as Mapk3)-knockout mice $\left(E r k 1^{-/-}\right.$mice) and pharmacological approaches.

Methods NAD(P)H, free cytosolic $\mathrm{Ca}^{2+}$ concentration and insulin secretion were determined in islets. ERK1 and ERK2 subplasmalemmal translocation and activity was monitored using total internal reflection fluorescence microscopy. ERK1/2, mitogen and stress-activated kinase1 (MSK1) and cAMP-responsive element-binding protein (CREB) activation
\end{abstract}

Electronic supplementary material The online version of this article (doi:10.1007/s00125-017-4356-6) contains peer-reviewed but unedited supplementary material, which is available to authorised users.

Magalie A. Ravier

magalie.ravier@igf.cnrs.fr

1 Institut de Génomique Fonctionnelle, Centre National de la Recherche Scientifique (CNRS), Inserm, Université de Montpellier, 141 Rue de la Cardonille, 34094 Montpellier CEDEX 5, France

2 Faculté de Médecine, Centre Méditerranéen de Médecine Moléculaire, Inserm U1065, Université de Nice Sophia Antipolis, Nice, France

3 Institute for Research on Cancer and Aging, Nice (IRCAN), Centre Antoine Lacassagne, Université de Nice Sophia Antipolis, Nice, France

4 Medical Biology Department, Centre Scientifique de Monaco (CSM), Monaco, Principality of Monaco were evaluated by western blot and/or immunocytochemistry. The islet mass was determined from pancreatic sections.

Results Glucose induced rapid subplasmalemmal recruitment of ERK1 and ERK2. When both ERK1 and ERK2 were inhibited simultaneously, the rapid transient peak of the first phase of glucose-induced insulin secretion was reduced by $40 \%$ $(p<0.01)$, although ERK1 did not appear to be involved in this process. By contrast, ERK1 was required for glucose-induced full activation of several targets involved in beta cell survival; MSK1 and CREB were less active in $E r k 1^{-/-}$mouse beta cells $(p<0.01)$ compared with $E r k I^{+/+}$mouse beta cells, and their phosphorylation could only be restored when ERK1 was re-expressed and not when ERK2 was overexpressed. Finally, the islet mass of Erk $1^{-/}$ mice was slightly increased in young animals (4-month-old mice) vs $\mathrm{Erkl}^{+/+}$mice (section occupied by islets [mean $\pm \mathrm{SEM}$ ]: $0.74 \% \pm 0.03 \%$ vs $0.62 \% \pm 0.04 \% ; p<0.05$ ), while older mice (10 months old) were less prone to age-associated pancreatic periinsulitis (infiltrated islets [mean $\pm \mathrm{SEM}$ ]: $7.51 \% \pm 1.34 \%$ vs $2.03 \% \pm 0.51 \% ; p<0.001)$.

Conclusions/interpretation ERK1 and ERK2 play specific roles in beta cells. ERK2 cannot always compensate for the lack of ERK1 but the absence of a clear-cut phenotype in $\mathrm{Erkl}^{-/}$ mice shows that ERK1 is dispensable in normal conditions.

Keywords Ageing · CREB · ERK1/2 · Insulin secretion * MSK1 $\cdot$ p90RSK $\cdot$ Pancreatic beta cell mass $\cdot$ Pancreatic islet biology $\cdot$ Peri-insulitis
Abbreviations
$\left[\mathrm{Ca}^{2+}\right]_{\mathrm{c}} \quad$ Free cytosolic $\mathrm{Ca}^{2+}$ concentration
CFP Cyan fluorescent protein
CREB Cyclic AMP-responsive element-binding protein
EKAR Extracellular signal-related kinase activity reporter 


$\begin{array}{ll}\text { ERK1/2 } & \text { Extracellular signal-related kinase 1 and 2 } \\ \text { GSIS } & \text { Glucose-stimulated insulin secretion } \\ \text { MEK } & \text { Mitogen-activated protein kinase kinase } \\ \text { MSK1 } & \text { Mitogen and stress-activated kinase 1 } \\ \text { PKA } & \text { Protein kinase A } \\ \text { p90RSK } & \text { p90 ribosomal S6 kinase } \\ \text { TIRF } & \text { Total internal reflection fluorescence } \\ \text { YFP } & \text { Yellow fluorescent protein }\end{array}$

\section{Introduction}

Insufficient insulin secretion from pancreatic beta cells, often associated with a decrease in beta cell mass, is a characteristic of type 2 diabetes [1]. Glucose-stimulated insulin secretion (GSIS) from beta cells is triggered by an increase in the free cytosolic $\mathrm{Ca}^{2+}$ concentration $\left(\left[\mathrm{Ca}^{2+}\right]_{\mathrm{c}}\right)[2-4]$. The serine/ threonine kinases, extracellular signal-related kinase 1 and 2 (ERK1/2), are activated by glucose in a $\mathrm{Ca}^{2+}$-dependent manner and regulate key transcription factors, insulin gene expression and beta cell survival $[5,6]$. Whether they also play a role in GSIS [7-10] is still under debate [11, 12], mainly because clonal beta cell lines and/or PD98059 (a mitogen-activated protein kinase kinase [MEK]1/2 inhibitor), which display off-target effects on $\mathrm{Ca}^{2+}$ influx [12], have been used.

In other tissues, ERK1 and ERK2 represent a major signalling pathway for proliferation, differentiation and cell death through the phosphorylation of many substrates [13, 14]. ERK1 and ERK2 share $\sim 85 \%$ identity and are the two major members of the ERK family [14]. Whether ERK1 and ERK2 are redundant or play distinct cellular roles is still disputed $[15,16]$. Although large functional overlaps between ERK1 and ERK2 exist [17], discrete phenotypes are observed when they are targeted individually, suggesting that each ERK isoform cannot completely substitute for the other [18-20], partly because their relative tissue distributions differ [21]. For example, although ERK1 and ERK2 are equally expressed in adipose tissues, ERK1 appears to be specifically involved in adipocyte differentiation [20] while ERK2 is much more abundant than ERK1 in the liver [20]. ERK1 and ERK2 seem to be equally expressed in pancreatic islets $[8,22]$ but their individual roles have never been investigated. Nonetheless, Erk1 (also known as Mapk3)-knockout mice (Erkl ${ }^{-/}$mice) are resistant to high-fat-diet-induced obesity and are protected from insulin resistance [20,23], and ERK1 expression is upregulated in islets isolated from $d b /+$ mice [24], indicating that ERK1 and ERK2 could be modulated differently during the progression of type 2 diabetes.

Erk2 (also known as Mapk1)-knockout mice (Erk2 ${ }^{-/}$ mice) are not viable [18], and we observed that Erk2 depletion in MIN6 cells induced massive beta cell death [8, 22], suggesting that specific deletion of Erk2 [25] in beta cells might not be a suitable model. Therefore, to discriminate between the roles of ERK1 and ERK2, we used Erk1 ${ }^{-/-}$mice and pharmacological inhibitors of MEK1/2. We revisited the roles of ERK1 and ERK2 in the regulation of GSIS from mouse islets and, for the first time in living beta cells, we monitored the recruitment and activity of ERK1 and ERK2 underneath the plasma membrane, using total internal reflection fluorescence (TIRF) microscopy. We also assessed the contributions of ERK1 and ERK2 to signalling cascades known to be involved in beta cell survival.

\section{Methods}

Materials All reagents were from Sigma-Aldrich (St Louis, MO, USA), except for U0126 (Calbiochem, La Jolla, CA, USA) and trametinib (Selleckchem, Houston, TX, USA).

Mice C57BL/6J mice were from Charles River (L'Arbresle, France). $\mathrm{Erkl}^{+/-}$mice were bred to generate $\mathrm{Erkl}^{+/+}$vs Erkl ${ }^{-/}$ mice [19]. Four-month-old or 10-month-old male mice were used. Studies complied with the animal welfare guidelines of the European Community and complied with the authorisation of the Ministry of Agriculture, France (D34-172-13). Mice were housed in a pathogen-free animal house, with a $12 \mathrm{~h}$ light/dark cycle and a temperature of $20^{\circ} \mathrm{C}$. Mice had free access to food $(4 \%[\mathrm{~kJ}]$ fat diet) and water.

MIN6 cells MIN6 cells were originally obtained from $\mathrm{H}$. Ishihara (Tokyo, Japan) and were grown in Dulbecco's modified Eagle's medium containing $25 \mathrm{mmol} / \mathrm{l}$ glucose and $15 \%$ (vol./vol.) FBS and $75 \mathrm{nmol} / \mathrm{l}$ mercaptoethanol. See ESM Methods for further details.

Preparations and solutions Isolated islets from collagenase digestion of the pancreas were used immediately or after overnight culture in RPMI-1640 medium containing $10 \mathrm{mmol} / \mathrm{l}$ glucose and 10\% (vol./vol.) FBS. Clusters of cells were prepared by dispersion of isolated islets with trypsin and plated on glass coverslips (refractive index $n=1.53$ ) in RPMI-1640 medium. The medium was a bicarbonate-buffered solution containing (in mmol/l): $\mathrm{NaCl} 120, \mathrm{KCl} 4.8, \mathrm{CaCl}_{2} 2.5$, $\mathrm{MgCl}_{2} 1.2$ and $\mathrm{NaHCO}_{3}$ 24. Medium was gassed with $\mathrm{O}_{2}: \mathrm{CO}_{2}(95: 5)$ to maintain $\mathrm{pH} 7.4$ and was supplemented with $1 \mathrm{mg} / \mathrm{ml} \mathrm{BSA}$. The islets/cells were preincubated for $1 \mathrm{~h}$ with MEK inhibitors U0126 (Calbiochem,), trametinib (Selleckchem) or PD0325901 (Sigma-Aldrich) prior to the experiments.

Insulin, NAD(P)H and $\left[\mathrm{Ca}^{2+}\right]_{\mathrm{c}}$ measurements Freshly isolated islets from 10-month-old mice or cultured islets from 4month-old mice were used. The insulin content of islets or pancreases were determined after extraction in acid-ethanol (see electronic supplementary materials (ESM) Methods for 
further details). For $\left[\mathrm{Ca}^{2+}\right]_{\mathrm{c}}$, islets were loaded with $2 \mu \mathrm{mol} / 1$ Fura2-Leak-Resistant-AM (Tef Labs, Austin, TX, USA) for $2 \mathrm{~h}$, placed into a temperature-controlled perifusion chamber and excited every $3 \mathrm{~s}$ at $340 \mathrm{~nm}$ and $380 \mathrm{~nm}$; the emitted light was recorded at $510 \mathrm{~nm}$. For NAD(P)H, islets were preincubated for $30 \mathrm{~min}$ in $1.1 \mathrm{mmol} / 1$ glucose and were then transferred to the same experimental setup that was used for $\left[\mathrm{Ca}^{2+}\right]_{\mathrm{c}}$ measurements. The reduced forms of NAD and NADP, (referred as $\mathrm{NAD}(\mathrm{P}) \mathrm{H})$ were excited at $360 \mathrm{~nm}$ every $36 \mathrm{~s}$ and the emitted light was recorded at $470 \mathrm{~nm}$.

Vectors and adenovirus generation Dispersed islet cells were infected for $4 \mathrm{~h}$ with adenoviruses. Briefly, ERK activity reporter (EKAR)-CeruleanVenus plasmid (www.addgene. com) was digested and the released fragment was ligated into EcoRV sites of pShuttle-CMV. For ERK1-yellow fluorescent protein (YFP) and/or ERK2-YFP (ATCC, Molsheim France), plasmids were digested and the released fragments were ligated into pShuttle-CMV (www. coloncancer.org/adeasy.htm). Recombination with pAdEasy1, transfection into HEK 293 cells (ATCC) and viral amplification were performed as described (www.coloncancer.org/ adeasy.htm). Probes were preferentially expressed in beta cells compared with non-beta-cells. See ESM Methods for further details.

Histological analysis, immunostaining of pancreas, TUNEL and immunocytochemistry of dispersed cells Pancreases were fixed with $4 \%$ (vol./vol.) formaldehyde, paraffin embedded and longitudinally sectioned through the pancreatic head-to-tail axis (4 $\mu \mathrm{m}$ thickness). Pancreas sections were stained with $\mathrm{H} \& \mathrm{E}$ or were incubated overnight at $4{ }^{\circ} \mathrm{C}$ with primary antibodies (ESM Table 1), followed by incubation for $1 \mathrm{~h}$ with secondary antibodies (ESM Table 1) and DAPI. The percentage of apoptotic islet beta cells (TUNELand insulin-positive cells) was determined using the In Situ Cell Death Detection Kit-TMR red (Roche Diagnostics, Mannheim, Germany) following the manufacturer's instructions. Overnight-cultured dispersed mouse islet cells were preincubated for $2 \mathrm{~h}$ in $1.1 \mathrm{mmol} / \mathrm{l}$ glucose and then stimulated with $16.7 \mathrm{mmol} / \mathrm{l}$ glucose for 10 or $20 \mathrm{~min}$ in the presence or absence of MEK inhibitors. Dispersed islet cells were fixed for $20 \mathrm{~min}$ (4\% formaldehyde; $80 \mathrm{mmol} / \mathrm{l} \mathrm{NaF}$ for phosphorylated proteins), incubated overnight with primary antibodies and then incubated for $1 \mathrm{~h}$ with secondary antibodies and DAPI (see ESM Table 1). For p-ERK1/2, a methanol treatment after paraformaldehyde fixation was required. See ESM Methods for further details. The antibodies used for immunocytochemistry were against insulin, glucagon, Ki-67, pERK1/2, phosphorylated mitogen and stress-activated kinase 1 (MSK1), phosphorylated cyclic AMP-responsive elementbinding protein (CREB), CD3 and CD8. All antibodies are commercially available (see ESM Table 1) and were validated by companies for immunofluorescence. Results were reproducible over time, using different antibody lots. Experimenters were blinded to group assignment.

TIRF microscopy A $\times 100$ lens with 1.49 numerical aperture was used. EKAR, a genetically encoded FRET-based sensor that reports ERK1/2 activation, was excited with a $405 \mathrm{~nm}$ laser (Roper Scientific, Evry, France) and the emitted light was filtered at $475 \mathrm{~nm}$ for cyan fluorescent protein (CFP) and $540 \mathrm{~nm}$ for venus, a variant of YFP. YFP was excited with a $491 \mathrm{~nm}$ laser (Roper Scientific) and the emitted light was filtered at $540 \mathrm{~nm}$. Images were collected every $10 \mathrm{~s}$ with $30 \mathrm{~ms}$ exposure using a charge-coupled device camera (Quantem; Roper Scientific) and MetaMorph software (Molecular Devices, Downingtown, PA, USA). Experiments were performed in a $37^{\circ} \mathrm{C}$ temperature-controlled perifusion chamber. See ESM Methods for further details.

Real-time quantitative RT-PCR Freshly isolated mouse islets were distributed in batches of 120-150 islets. Total RNAs were extracted and DNase-treated using the RNAeasy microkit (Qiagen, Courtaboeuf, France) and then reversetranscribed with MoMuLVRT (Life Technology, Paisley, UK), according to the manufacturers' instructions. To quantify the expression of genes, we designed and validated primer pairs (Qiagen-Operon; see ESM Table 2 for primer sequences) for real-time quantitative PCR, which was performed with Roche LC480 and the Light Cycler 480 SybrGreen Master Mix (Roche Diagnostics). The level of expression of each gene was normalised to the geometric mean of the levels of expression of Hprt and Tubb2a. The genes analysed were Ins2, Ins1, Erk2, Irs2. See ESM Methods for further details.

Western blotting of mouse islet samples Freshly isolated mouse islets were distributed in batches of 120-150, preincubated for $2 \mathrm{~h}$ in bicarbonate buffer with $1.1 \mathrm{mmol} / \mathrm{l}$ glucose and then stimulated with $16.7 \mathrm{mmol} / \mathrm{l}$ glucose for $20 \mathrm{~min}$, as detailed above. A $2 \mathrm{~h}$ preincubation in $1.1 \mathrm{mmol} / \mathrm{l}$ glucose did not trigger apoptosis (ESM Fig. 1). At the end of the incubation with glucose, MIN6 cells, mouse islets or dispersed islets cells were washed with ice-cold PBS and lysed in NP40 lysis buffer. The antibodies used for western blotting were against $\beta$-actin, p-ERK1/2, phosphorylated p90 ribosomal S6 kinase (p90RSK), p-MSK1, p-CREB, total ERK1/2, total CREB, cleaved caspase 3 and glyceraldehyde 3-phosphate dehydrogenase (GAPDH). See ESM Methods for further details and ESM Table 1 for antibodies. All antibodies were commercially available (see ESM Table 1) and were validated by companies for western blotting. All antibodies produced bands that were at the expected molecular weights for the targeted proteins. Results were reproducible over time with different antibody lots. 
Blood glucose, glucose and insulin tolerance tests, and plasma insulin or glucagon measurements Blood glucose levels were measured using a OneTouch Verio glucometer (LifeScan Issy les Moulineaux, France). Glucose tolerance tests were performed on overnight-fasted mice. Blood glucose levels were measured before ( $0 \mathrm{~min})$ and 15, 30, 60, 90, 120 and $150 \mathrm{~min}$ after i.p. glucose injection $(1.5 \mathrm{~g} / \mathrm{kg}$ body weight). Insulin tolerance tests were performed on $4 \mathrm{~h}$-fasted mice. Blood glucose levels were measured before $(0 \mathrm{~min})$ and $15,30,60,90,120$ and $150 \mathrm{~min}$ after i.p. insulin injection (0.75 U/kg body weight) (Umuline; Lilly, Giessen, Germany). Plasma insulin was determined using the Ultra Sensitive Mouse Insulin ELISA Kit (Crystal Chem, Zaandam, Netherlands). Plasma glucagon was determined using a glucagon radioimmunoassay kit (Millipore, $\mathrm{St}$ Charles, MO, USA).

Statistical analysis Data are shown as means \pm SEM for the indicated number of observations. For kinetic experiments, SEM are indicated only at selected time points. GraphPad Prism 7.2 software (GraphPad, La Jolla, CA, USA) was used. Samples were not randomised. All data obtained during the experiments were analysed. Statistically significant differences between groups were assessed by Student's $t$ test or by ANOVA. For ANOVA, when the global factor effect was shown to be significant, post hoc tests for multiple comparisons (indicated in figure legends) were performed to obtain adjusted $p$ values. One-way ANOVA was followed by Sidak's post hoc test when selected pairs of columns were compared, or by Dunnett's test when columns were compared with a control column. Two-way ANOVA was followed by Tukey's post hoc testing for multiple comparisons.

\section{Results}

ERK1 and ERK2 are recruited underneath the plasma membrane by glucose and ERK activity contributes to the first phase of insulin secretion in mouse islets The role of ERK1/2 on GSIS was reinvestigated in mouse islets using U0126, which displays fewer side effects than PD98059 [12, 26]. Nevertheless, $10 \mu \mathrm{mol} / 1 \mathrm{U} 0126$ (a widely used concentration $[12,26]$ ) reduced glucose metabolism by $50 \%$ (ESM Fig. 2a), reflected by reduced $\mathrm{NAD}(\mathrm{P}) \mathrm{H}$ fluorescence and, consequently, smaller glucose-induced $\left[\mathrm{Ca}^{2+}\right]_{\mathrm{c}}$ increases (ESM Fig. 2b). By contrast, $1 \mu \mathrm{mol} / 1 \mathrm{U} 0126$ did not affect glucose-induced (16.7 mmol/l) glucose metabolism (Fig. 1a), $\left[\mathrm{Ca}^{2+}\right]_{\mathrm{c}}$ amplitude (Fig. 1b) or $\left[\mathrm{Ca}^{2+}\right]_{\mathrm{c}}$ oscillation frequencies $(0.531 \pm 0.030$ vs $0.587 \pm 0.052$ oscillations $/ \mathrm{min}$, without U0126 vs with U0126), but it reduced the rapid transient peak of the first phase of GSIS by $40 \%$ (Fig. 1c, ESM Fig. 3c). U0126 did not significantly affect the sustained second phase (Fig. 1c). Similar results were observed with two other specific MEK inhibitors, trametinib (also called GSK1120212 [27]) and PD0325901 [12, 28] (ESM Fig. $3 \mathrm{a}, \mathrm{b})$, although trametinib $(52 \%)$ appeared to be more efficient than U0126 (40\%) or PD0325901 (40\%) at reducing the first phase of GSIS (ESM Fig. 3c). A sixfold increase in ERK1/2 phosphorylation after $10 \mathrm{~min}$ of stimulation with $16.7 \mathrm{mmol} / 1$ glucose (i.e. during the first phase of GSIS) was measured by immunocytochemistry in mouse beta cells (Fig. 1d, e; ESM Fig. 3d, e), while only a twofold increase remained after 20 min of stimulation (i.e. during the second phase; Fig. 1f), as already revealed by western blotting [22]. U0126 repressed the cytosolic phosphorylation of ERK1/2 induced by $16.7 \mathrm{mmol} / \mathrm{l}$ glucose by $90 \%$ (Fig. $1 \mathrm{~d}-\mathrm{f}$ ), while it was completely suppressed by trametinib and PD0325901 (ESM Fig. 3d, e).

To determine whether ERK1/2 are actively recruited underneath the plasma membrane, the fluorescence of EKAR, a genetically encoded FRET-based sensor that reports ERK1/2 activation [29], was imaged using TIRF microscopy [30] in living mouse beta cells. EKAR fluorescence intensity was increased by $16.7 \mathrm{mmol} / 1$ glucose $(p<0.01)$, reaching a maximum intensity $9 \mathrm{~min}$ after stimulation (Fig. 1g); this response was suppressed by U0126 (Fig. 1g). This indicates that native ERK1/2 phosphorylated EKAR beneath the plasma membrane. Moreover, $16.7 \mathrm{mmol} / \mathrm{l}$ glucose induced recruitment of both ERK1 (ERK1-YFP, Fig. 1h) and ERK2 (ERK2YFP, Fig. 1i) underneath the plasma membrane, reaching maximum recruitment after 9 min of stimulation; this action was blocked by U0126 (Fig. 1h; data not shown for ERK2YFP) and was absent when YFP was expressed alone (Fig. 1i). Thus, our data suggest that ERK $1 / 2$ are rapidly recruited beneath the plasma membrane by glucose and contribute to the first phase of GSIS.

ERK1 is required for glucose-induced full activation of p90RSK, MSK1 and, consequently, CREB, but not for insulin gene expression $E r k 1^{-1-}$ mice were used to determine the respective roles of ERK1 and ERK2 in beta cells. ERK1 and ERK2 were equally expressed in $E r k 1^{+/+}$mouse islets (Fig. 2b, c). Erk2 mRNA levels (Fig. 2a), ERK2 expression (Fig. 2b, c) and glucose-induced ERK2 phosphorylation (Fig. 2b, d) were similar in $E r k 1^{+/+}$and $E r k 1^{-/-}$mouse islets, indicating that there was no compensatory upregulation of ERK2 in $\mathrm{Erk1}^{-/-}$mouse islets.

p90RSK and MSK1 are two main kinases that are directly phosphorylated by ERK1/2 in the cytoplasm and, in turn, phosphorylate nuclear targets [14, 31]. Basal phosphorylation (at $1.1 \mathrm{mmol} / 1$ glucose) of p90RSK and MSK1 was similar in $\mathrm{Erkl}^{-/-}$and $\mathrm{Erkl}^{+/+}$mouse islets (Fig. 3a), while glucoseinduced $(16.7 \mathrm{mmol} / \mathrm{l})$ phosphorylation of p90RSK and MSK1 was significantly reduced $(p<0.01)$ in $E r k 1^{-/-}$mouse islets by $\sim 50 \%$ and $\sim 70 \%$, respectively (Fig. 3a). Since the adenoviral infection of the whole islet accounts for only two 

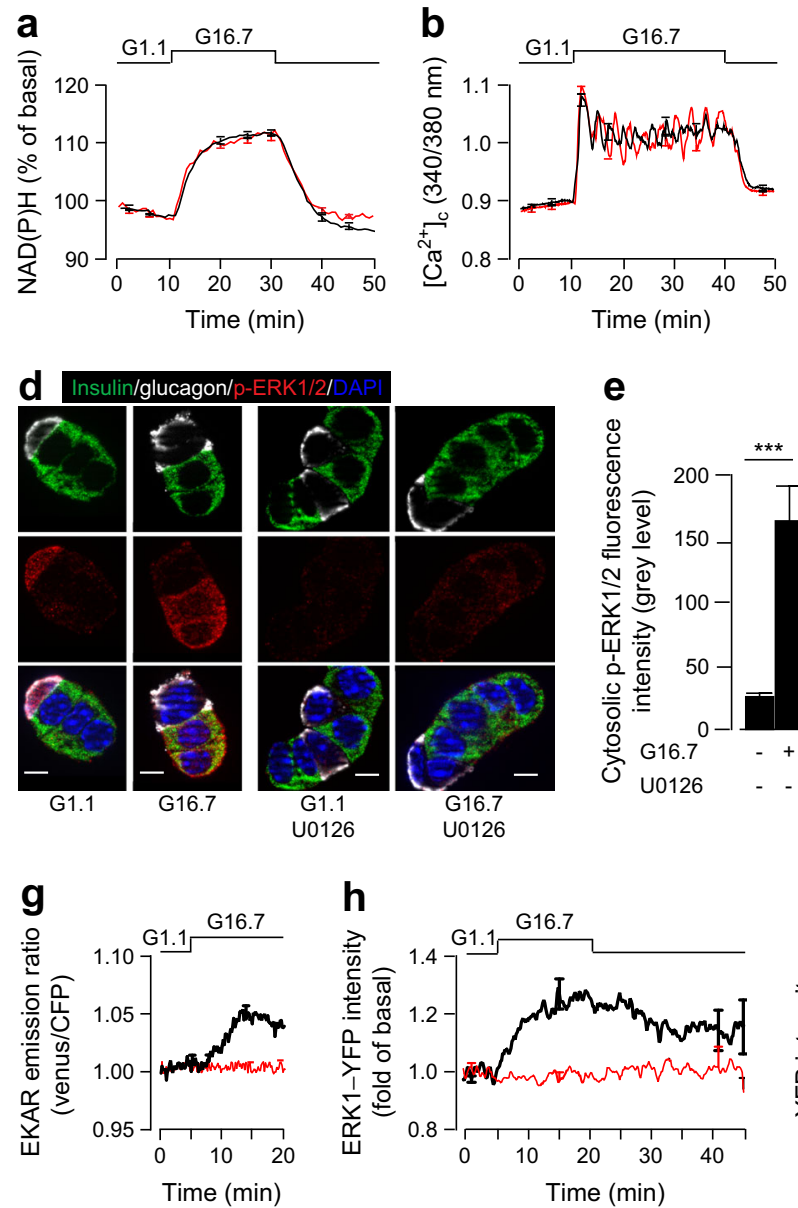

Fig. 1 ERK1 and ERK2 are recruited beneath the plasma membrane and ERK activity contributes to the first phase of GSIS. (a-c) Glucose was increased from $1.1 \mathrm{mmol} / \mathrm{l}$ (G1.1) to $16.7 \mathrm{mmol} / \mathrm{l}$ (G16.7) in overnightcultured mouse islets in the presence (red trace/bar) or absence (black trace/bar) of $1 \mu \mathrm{mol} / 1 \mathrm{U} 0126$. (a) $\mathrm{NAD}(\mathrm{P}) \mathrm{H},(\mathbf{b})\left[\mathrm{Ca}^{2+}\right]_{\mathrm{c}}$ and (c) insulin secretion were measured in islets. Insets show the AUC of GSIS during the first phase (10-20 min) and second phase (25-67 min). Data are means \pm SEM; (a, b) $n=4$, (c) $n=8$; ${ }^{* *} p<0.01$ (paired $t$ test of islets isolated from the same mouse treated or not treated with U0126). (d) Immunocytochemistry of p-ERK $1 / 2$ in dispersed islet cells stimulated

or three layers of cells (M.A. Ravier personal observations and [32]), ERK1 was re-expressed in dispersed $\mathrm{Erk1}^{-/-}$beta cells using ERK1-YFP, and MSK1 activation was assessed by immunocytochemistry. Glucose-induced activation of MSK1 was completely restored when ERK1 was re-expressed in $E r k 1^{-1-}$ mouse beta cells (Fig. 3b, c). This was in sharp contrast to findings in cells that overexpressed ERK2 (ERK2YFP) or expressed YFP alone (Fig. 3b, c). The lack of efficacy of ERK2 overexpression was not caused by a deficiency of ERK2-YFP activity since it was functional in MIN6 cells (ESM Fig. 4). ERK1 was, therefore, specifically required for glucose-induced full MSK1 activation.

Once activated, p90RSK and MSK1 lead to CREB phosphorylation $[14,31]$. Expression and basal phosphorylation of CREB were similar in $\mathrm{Erkl}^{+/+}$and $\mathrm{Erkl}^{-/-}$mouse islets (Fig. 4a), while its activation by $16.7 \mathrm{mmol} / \mathrm{l}$ glucose was repressed
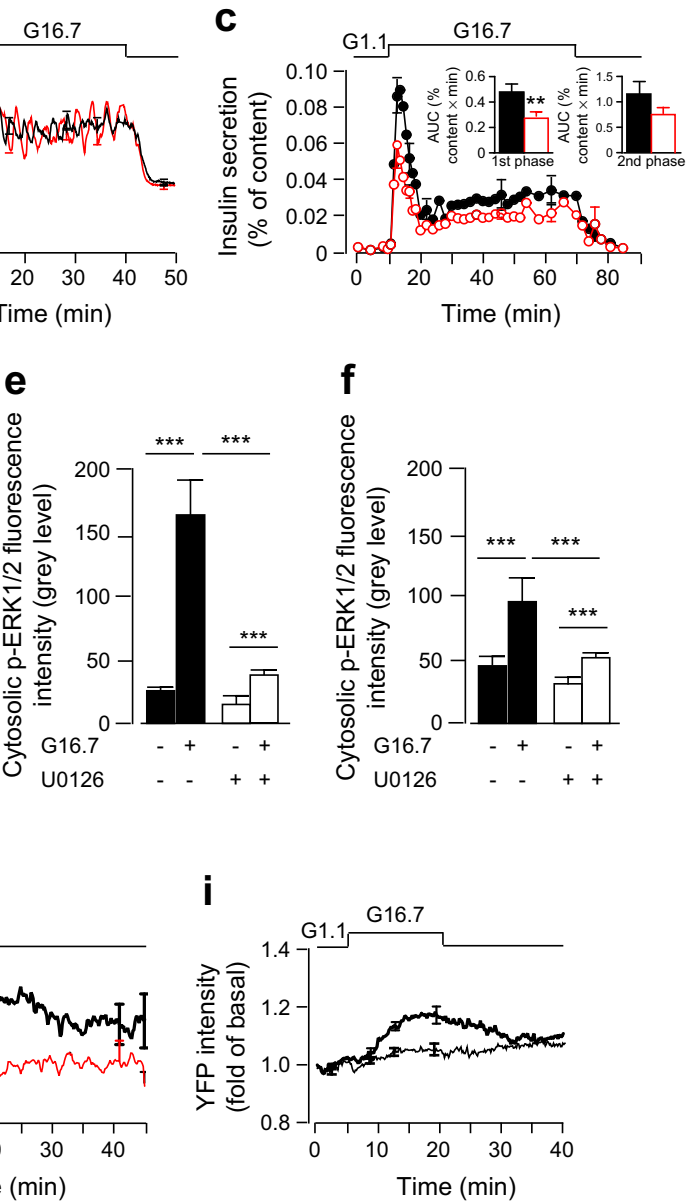

with G16.7 for 10 min. Scale bars, $5 \mu \mathrm{m}$. (e, f) Cytosolic p-ERK1/2 immunofluorescence intensity analysis in dispersed islet cells treated with or without $1 \mu \mathrm{mol} / 1 \mathrm{U} 0126$ and G16.7 for (e) $10 \mathrm{~min}$ or (f) $20 \mathrm{~min}$. Data are means \pm SEM; $n=3$; *** $p<0.001$ (two-way ANOVA followed by Tukey's post test) for indicated comparisons. (g) ERK1/2 activation, (h) ERK1-YFP and (i) ERK2-YFP (thick trace) or YFP (thin trace) measurements by TIRF microscopy in dispersed islet cells. Data are means \pm SEM: $n=10$ cells ( 6 mice) or $n=15$ cells ( 9 mice; thick traces). Black trace, without U0126, red trace, with U0126

by $\sim 65 \%$ in $\mathrm{Erkl}^{-/-}$mouse islets (Fig. 4a-c). Again, the reexpression of ERK1 in Erk1 ${ }^{-/}$mouse beta cells was sufficient to almost completely restore the nuclear activation of CREB induced by $16.7 \mathrm{mmol} / \mathrm{l}$ glucose, while the overexpression of ERK2-YFP did not have the same effect (Fig. 4b, c). CREB regulates the expression of genes, such as Irs2, that are crucial for beta cell survival [22, 33, 34]. Nevertheless, the mRNA level of Irs2 was unchanged in Erk1 ${ }^{-/-}$vs $E r k I^{+/+}$mouse islets (Fig. 4d). Therefore, ERK1 is specifically required to fully activate CREB by glucose, but is not required for Irs 2 expression.

Finally, it has been reported that glucose-induced ERK1/2 activation plays an important role in insulin gene transcription through the direct regulation of transcription factors that bind to the insulin gene promoter [5]. Ins 1 and Ins 2 mRNA levels (Fig. 4d) and the insulin content in size-matched islets (Fig. 4e) were not affected in $\mathrm{ErkI}^{-/-}$mouse islets. Therefore, 


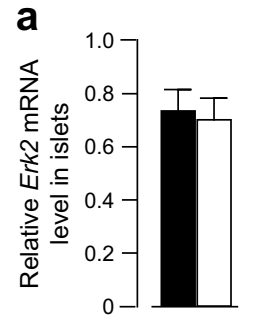

b
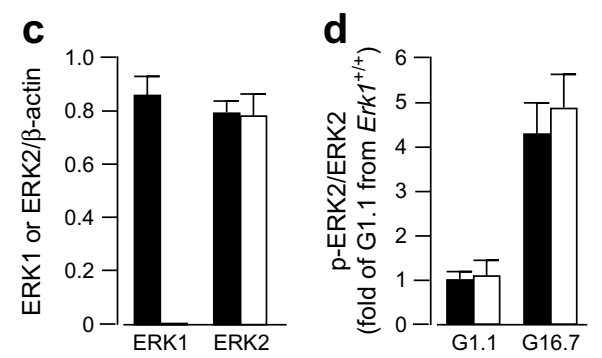

Fig. 2 ERK2 signalling is not upregulated in $E r k 1^{-/-}$mouse islets. (a) Erk2 mRNA levels relative to the geometric mean of Hprt and Tubb2a expression. (b) Representative immunoblots of ERK1 and ERK2 expression and phosphorylation and (c, d) quantitative analysis. Data are means $\pm \mathrm{SEM}$; $n=5$. Black bars, Erk1 ${ }^{+/+}$mouse islets, white bars, Erkl ${ }^{-/-}$mouse islets. G1.1, $1.1 \mathrm{mmol} / \mathrm{l}$ glucose; G16.7, $16.7 \mathrm{mmol} / \mathrm{l}$ glucose

ERK1 does not appear to play a major role in the regulation of insulin gene expression.
ERK1 is not required for GSIS Since the absence of ERK1 altered the activation of p90RSK, MSK1 and, consequently, CREB, the impact of ERK1 depletion in living mice was investigated. When comparing $E r k l^{-/}$mice with $\mathrm{Erk1}^{+/+}$mice, blood glucose levels were similar after refeeding (Fig. 5a) or when the mice were fed ad libitum (Fig. 5b). Neither plasma insulin (Fig. 5c) nor plasma glucagon (Fig. 5d) differed in the fed state. Erk1 ${ }^{-/-}$mice were not glucose intolerant (Fig. 5e) and displayed similar insulin sensitivity (Fig. 5f) when compared with $E r k 1^{+/+}$ mice. Furthermore, glucose induced similar changes in $\left[\mathrm{Ca}^{2+}\right]_{\mathrm{c}}$ (Fig. 6a) and insulin secretion (Fig. 6b) in islets isolated from $\mathrm{Erkl}^{+/+}$and Erkl ${ }^{-/-}$mice, indicating that ERK1 does not contribute to the first phase of GSIS. Finally, there was only a $25 \%(p<0.05)$ decrease in subplasmalemmal ERK activity measured by TIRF microscopy in Erk1 $1^{-1-}$ mouse beta cells, and this activity was suppressed by U0126 (Fig. 6c). To ascertain whether there was any relocation of ERK2 from the nucleus to the cytosol to compensate for the absence of ERK1 in Erk1 ${ }^{-1}$ beta cells, ERK1/2 phosphorylation was measured in the cytosol and in the nucleus. Similar decreases in p-ERK in the nucleus ( $\sim 30 \%$; Fig. $6 \mathrm{~d}$, e) and in the cytosol $(\sim 35 \%$; Fig. 6d, f) were observed when comparing $\operatorname{Erkl}^{-/-}$with
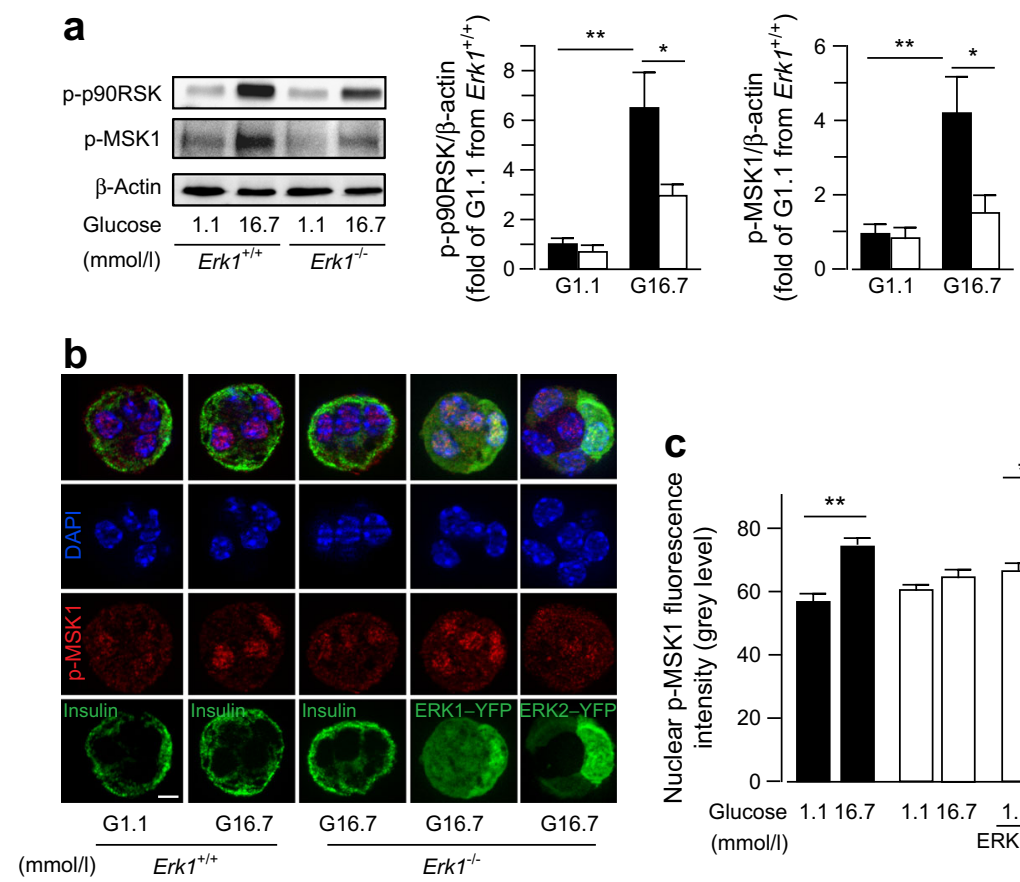

Fig. 3 ERK1 is required for glucose-induced full activation of p90RSK and MSK1 in mouse beta cells. (a) Representative immunoblots of pp90RSK and p-MSK 1 and quantitative analysis. Data are means \pm SEM; $n=6$; $p<0.05, * * p<0.01$ for indicated comparisons (two-way ANOVA followed by Tukey's post test). (b) Immunocytochemistry of p-MSK1 in dispersed islet cells from $\mathrm{Erkl}^{+/+}$or $\mathrm{Erkl}^{-1-}$ mice. Cells were either unstimulated (exposed to $1.1 \mathrm{mmol} / \mathrm{l}$ glucose [G1.1]) or were stimulated with $16.7 \mathrm{mmol} / 1$ glucose (G16.7). Insulin immunoreactivity or ERK1YFP- or ERK2-YFP-expressing cells are shown. For ERK1-YFP, four

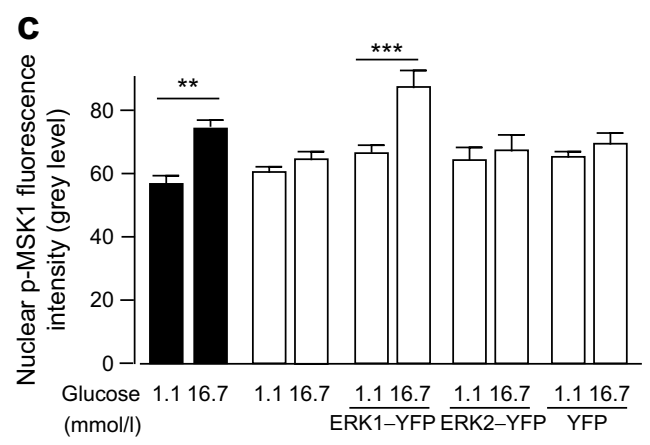

out of four cells expressed ERK1-YFP, whilst for ERK2-YFP, three out of five cells expressed ERK2-YFP. Scale bars, $5 \mu \mathrm{m}$. (c) Quantification of p-MSK1 immunofluorescence from (b); Only cells expressing insulin, ERK1-YFP or ERK2-YFP were analysed (see ESM Methods). Data are means \pm SEM; $n=6$, except for ERK2-YFP $(n=4)$ and YFP $(n=3)$; $* * p<0.01, * * * p<0.001$ compared with corresponding G1.1 control value (one-way ANOVA followed by Sidak's post test). Black bars, $\mathrm{ErkI}^{+/+}$mouse beta cells, white bars, ErkI ${ }^{-/-}$mouse beta cells 
a
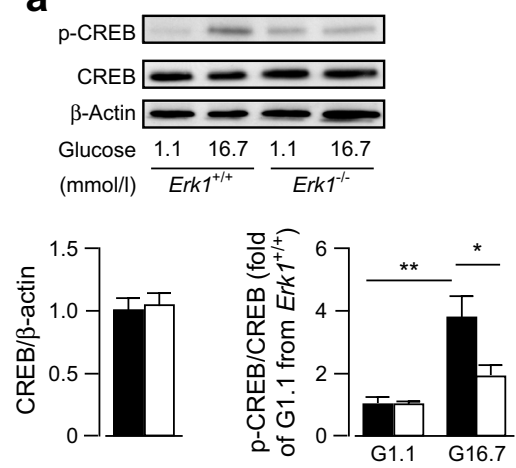

b
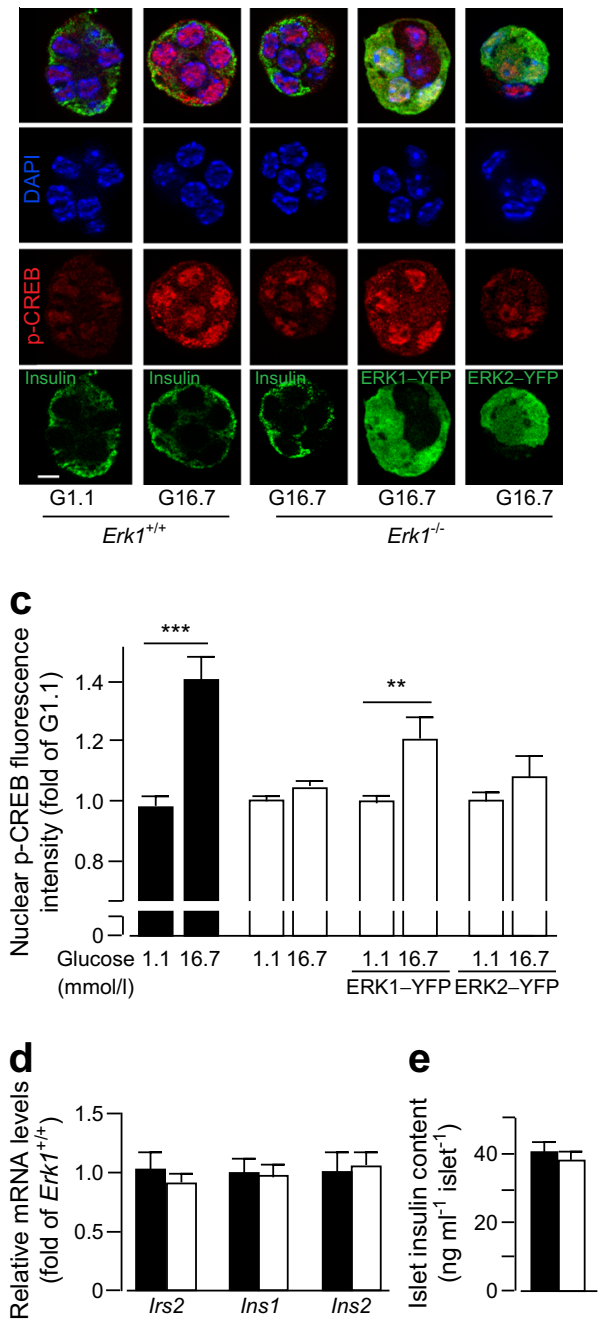

Erk1 ${ }^{+/+}$mouse beta cells exposed to $16.7 \mathrm{mmol} / 1$ glucose. Consequently, the proportion of p-ERK in the cytosol compared with the total amount of activated ERK in the cell (i.e. cytosol + nucleus) remained unchanged in $E r k l^{-/-}$vs $E r k 1^{+/+}$ mice (Fig. 6g). Altogether, our results suggest that, although glucose recruits ERK1 underneath the plasma membrane in wild-type mice, ERK2 activity is likely sufficient for the full regulation of the first phase of insulin secretion in $\mathrm{Erkl}^{-/}$ mice.
Fig. 4 ERK1 is required for glucose-induced full activation of CREB but not for Irs 2 or insulin gene expression in mouse islet cells. (a) Representative immunoblots of CREB expression and phosphorylation and quantitative analysis. Data are means \pm SEM; $n=5 ;{ }^{*} p<0.05$, $* * p<0.01$ for indicated comparisons (two-way ANOVA followed by Tukey's post test). (b) p-CREB immunocytochemistry in dispersed islet cells from $\mathrm{Erkl}^{+/+}$or $\mathrm{Erkl}^{-/-}$mice. Cells were either unstimulated (exposed to $1.1 \mathrm{mmol} / 1$ glucose [G1.1]) or stimulated (with $16.7 \mathrm{mmol} / 1$ glucose [G16.7]). Insulin immunoreactivity or ERK1-YFP- or ERK2YFP-expressing cells are shown. For ERK1-YFP, three out of five cells expressed ERK1-YFP, while for ERK2-YFP, three out of four cells expressed ERK2-YFP. Scale bars, $5 \mu \mathrm{m}$. (c) Quantification of p-CREB immunofluorescence from (b); only cells expressing insulin, ERK1-YFP or ERK2-YFP were analysed (see ESM Methods). Data are means $\pm \mathrm{SEM} ; n=6$ (with and without ERK1-YFP) or $n=4$ (ERK2YFP); $* * p<0.01$ and $* * * p<0.001$ for indicated comparisons (one-way ANOVA followed by Sidak's post test). (d) Irs2, Ins 1 and Ins 2 mRNA levels. (e) Insulin content in isolated islets. Data are means \pm SEM; $n=5$. Black bars, $E r k I^{+/+}$mouse islets, white bars, Erkl ${ }^{-/}$mouse islets

ERK1 contributes to the regulation of the islet mass and to the pancreatic peri-insulitis caused by ageing Since ERK1 was required for glucose-induced full activation of MSK1 and CREB, and because ERK1/2 have been reported to play a role in beta cell survival [5], the islet mass was investigated in 4month-old $E r k 1^{-/-}$mouse pancreases. Compared with $E r k 1^{+/+}$ mice, the number of islets in each pancreas section was similar in $E r k 1^{--}$mice (Fig. 7a, b) but the percentage of the pancreas section area occupied by islets was increased in $E r k 1^{-/-}$mouse pancreases (section occupied by islets [mean \pm SEM]: $0.74 \% \pm 0.03 \%$ vs $0.62 \% \pm 0.04 \%$, Erkl $^{-/-}$vs Erkl ${ }^{+/+}$mice; Fig. 7c) owing to a modified distribution of islet sizes (decreased proportion of small islets and increased proportion of large islets; Fig. 7d). Consequently, the wholepancreas insulin content was slightly increased (Fig. 7e) in
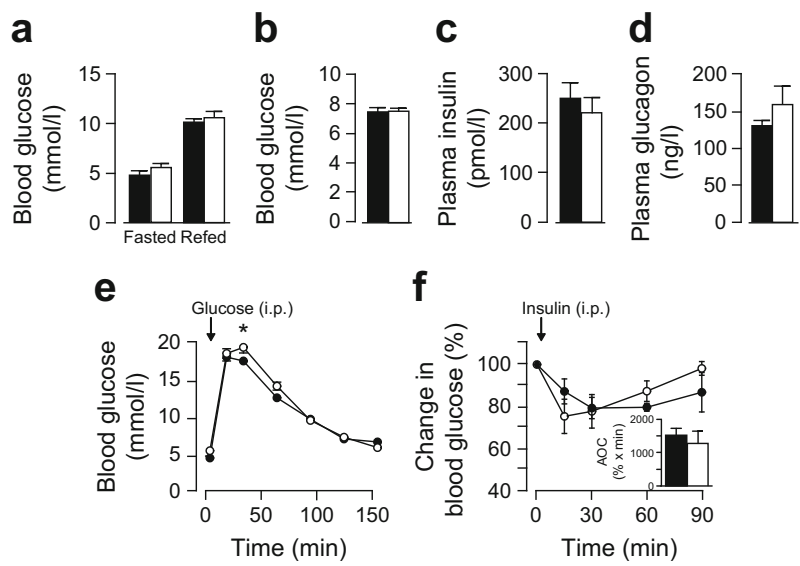

Fig. $5 \mathrm{Erkl}^{-/-}$and $\mathrm{Erkl}^{+/+}$mice display similar glucose tolerance and insulin sensitivity. (a) Blood glucose levels before (fasted) and $3 \mathrm{~h}$ after refeeding. (b) Fed (ad libitum) blood glucose, (c) plasma insulin and (d) glucagon levels. (e) i.p. glucose and (f) insulin tolerance tests. Arrows indicate the time of i.p. injection of (e) glucose or (f) insulin. Inset shows area over the curve (AOC). Data are means \pm SEM; (a-d) $n=24$ mice, (e) $n=18$ mice or (f) $n=6$ mice. $* p<0.05$, compared with $E r k 1^{+/+}$mice (Student's $t$ test). Black bars/circles, $E r k I^{+/+}$mice, white bars/circles, $\mathrm{Erkl}^{-/-}$mice 

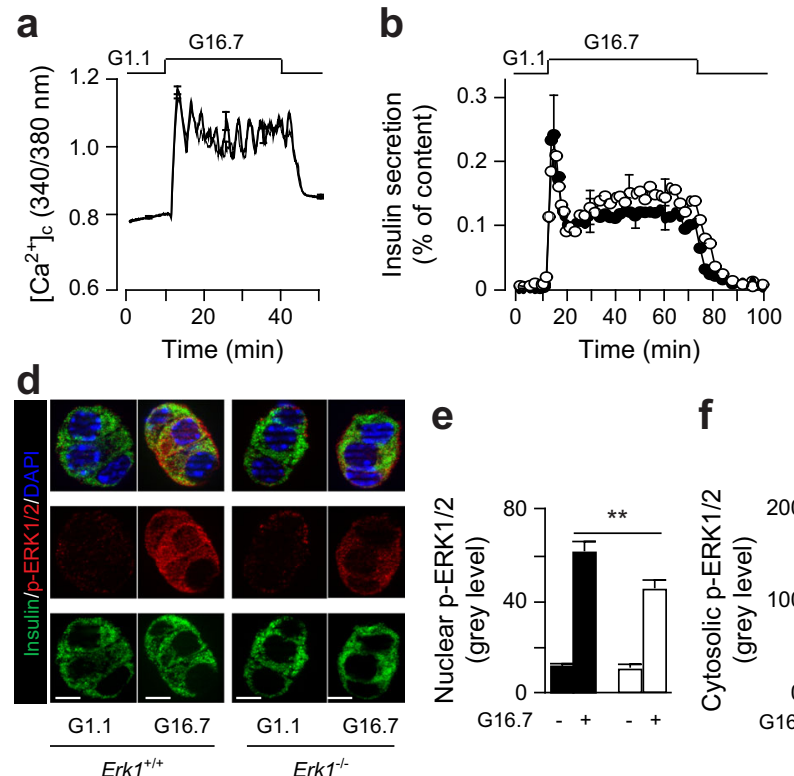

C

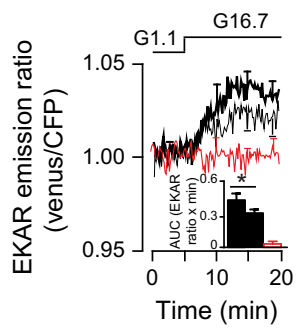

Fig. 6 Glucose induces subplasmalemmal ERK1 recruitment that is not involved in GSIS. (a) $\left[\mathrm{Ca}^{2+}\right]_{\mathrm{c}}$ and (b) insulin secretion in overnight-cultured mouse islets. Data are means $\pm \mathrm{SEM}$; (a) $n=4$ or (b) $n=5$. (c) ERK1/2 activation imaged by TIRF microscopy in islet cells. Inset show AUC. Data are means \pm SEM; $n=16$ cells $\left(E r k l^{+/+}\right), n=18$ cells $\left(E r k l^{-/}\right)$and $n=8$ cells (U0126; $E r k 1^{-/}$) from 8 mice; ${ }^{*} p<0.05$ for indicated comparison (one-way ANOVA followed by Dunnett's post test). (d) Representative images (scale bars, $5 \mu \mathrm{m}$ ) and (e-f) quantification of p-ERK1/2 immunostaining in the (e)

$E r k 1^{-1-}$ mice. Although the islet architecture was maintained in $\mathrm{ErkI}^{-/-}$pancreases (Fig. 7f), beta but not alpha cell (Fig. 7g) numbers were significantly increased, in agreement with the global increase in islet size (Fig. 7c, d). The percentage of Ki67-positive beta cells, reflecting proliferation, was similar in $\mathrm{Erkl}^{+/+}$and $\mathrm{Erkl}^{-/-}$beta cells (Fig. 7h). Cleavage of caspase 3, a marker of apoptosis, was not detected by western blot (ESM Fig. 1). To ensure that we did not miss low-level apoptosis, TUNEL staining of pancreatic slices was also performed. There was a more pronounced occurrence of beta cell TUNEL staining in $E r k 1^{-/-}$mouse pancreases $(1.13 \pm 0.64 \mathrm{vs}$ $3.60 \pm 0.7 \%$ of islets, $E r k l^{+/+}$vs Erkl ${ }^{-/} ; p<0.05$ ) (Fig. 7i, j). Of the eight pancreas slices examined in each group, only three of those from $\mathrm{ErkI}^{+/+}$mice displayed TUNEL-positive beta cells while all slices from the $E r k 1^{-/}$mice displayed signs of apoptosis (Fig. 7j), which was detected in both small and large islets (Fig. 7i, k). Nevertheless, this occurrence was minor relative to the total amount of islet per slice (Fig. 7j).

To determine whether the slight increase in islet mass with Erk1-knockout persisted in older mice, islet mass was assessed in 10-month-old animals (Fig. 8). Compared with $\mathrm{Erkl}^{+/+}$mice, the islet number in $\mathrm{Erkl}^{-/-}$remained unaffected at 10 months (Fig. 8a, b), while the differences in islet mass seen in 4-month-old mice were not observed in the aged animals (Fig. 8c, d). Indeed, 10-month-old Erkl ${ }^{+/+}$mice displayed fewer small islets $(37.05 \pm 1.82$ vs $45.11 \pm 1.55 \%$, $\mathrm{Erkl}^{-/-}$vs $\mathrm{Erkl}^{+/+}$mice; $\left.p<0.01\right)$ and appeared to have more nucleus and (f) cytosol after $10 \mathrm{~min}$ stimulation with $16.7 \mathrm{mmol} / \mathrm{l}$ glucose (G16.7) or with $1.1 \mathrm{mmol} / \mathrm{l}$ glucose (G1.1). (g) Cytosolic p-ERK1/2 content expressed as a percentage of total p-ERK1/2 (cytosol + nucleus). Data are means $\pm \mathrm{SEM} ; n=4$; ** $p<0.01$ for indicated comparisons (two-way ANOVA followed by Tukey's post test). Thick trace/black bars/black circles, $E r k I^{+/+}$mouse islets; thin trace/white bars/white circles, $E r k 1^{-/}$mouse islets; red trace, $\mathrm{Erkl}^{-/-}$mouse islets in the presence of U0126

large islets ( $3.4 \pm 0.8$ vs $2.24 \pm 0.4)$ compared with 4-monthold mice (Figs $7 \mathrm{~d}$ and $8 \mathrm{~d}$ ). By contrast, small and large islets in 4- and 10-month-old Erk1 ${ }^{-1-}$ mice displayed a similar occupation of pancreatic sections. Strikingly, in aged $E r k I^{+/+}$mice, a significant amount of peri-insulitis, characterised by the presence of mononuclear cells at the base of the islets, was observed (Fig. 8e, f). This infiltrating mass was composed of $\mathrm{CD}^{+}$and $\mathrm{CD} 8^{+} \mathrm{T}$ cells (Fig. 8f) and, also, $\mathrm{CD} 4^{+} \mathrm{T}$ cells (not shown). Compared with $E r k 1^{+/+}$mouse pancreases, those from $\mathrm{Erkl}^{-/-}$mice presented a lower level of peri-insulitis (infiltrated islets [mean \pm SEM]: $7.51 \% \pm 1.34 \%$ vs $2.03 \% \pm 0.51 \%$; Fig. $8 \mathrm{~g}$ ). Consequently, at the age of 10 months, $E r k l^{-/-}$mice displayed better glucose tolerance than $E_{r k 1}{ }^{+/+}$mice (Fig. 8h). Both plasma insulin level $(0.425 \pm 0.065$ vs $0.346 \pm 0.045 \mathrm{ng} / \mathrm{ml} ; n=9 ; 15 \mathrm{~min}$ after i.p. glucose injection) and insulin sensitivity (Fig. 8i) were increased in $\mathrm{Erkl}^{-/-}$mice vs $\mathrm{Erkl}^{+/+}$mice, but these increases did not reach statistical significance. Glucose-induced $\left[\mathrm{Ca}^{2+}\right]_{\mathrm{c}}$ changes (Fig. 8j) and insulin secretion (Fig. 8k) from freshly isolated islets were also similar in 10-month-old $\mathrm{Erkl}^{-/-}$and $\mathrm{ErkI}^{+/+}$mice. A reduced adiposity [20] was unlikely to be involved in reduced pancreatic inflammation, as in aged mice the fat weights were similar (epididymal fat $2.64 \pm 0.49 \mathrm{~g} /$ $100 \mathrm{~g}$ body weight in $E r k 1^{+/+}$vs $3.44 \pm 0.52 \mathrm{~g} / 100 \mathrm{~g}$ body weight in $E r k l^{-/-}$mice; $n=11$ ); on the contrary, 4-month-old mice displayed a reduced fat weight (epididymal fat $3.65 \pm 0.54 \mathrm{~g} / 100 \mathrm{~g}$ body weight in $\mathrm{Erk1}^{+/+}$vs 
Fig. 7 ERK1 is involved in the regulation of beta cell mass growth. (a) Representative microphotographs of mouse pancreatic sections stained with H\&E. (b) Islet number, (c) per cent of section occupied by islets and (d) islet distribution per pancreatic section. (e) Wholepancreas insulin content. (f) Insulin and glucagon immunostaining of pancreatic sections. (g) Number of beta and alpha cells per islet. (h) Ki67 immunostaining of pancreatic sections and quantification. Arrows indicate Ki67-positive nuclei. (i) TUNEL staining and (j, k) quantification. Scale bars, $100 \mu \mathrm{m}$; data are means \pm SEM; (a-h) $n=12$ mice or (i-k) $n=8$ mice; $* p<0.05$ compared with $\mathrm{ErkI}^{+/+}$mouse cells (Student's $t$ test). Black bars/circles, ErkI ${ }^{+/+}$ mouse cells; white bars/circles, $\mathrm{Erk1}^{-/-}$mouse cells a

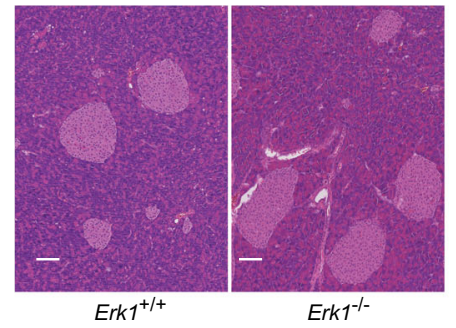

b
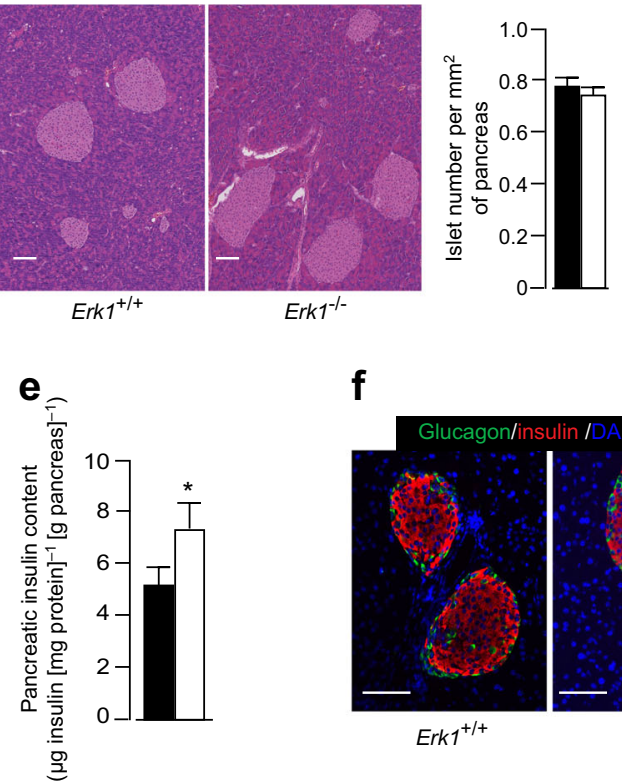

f

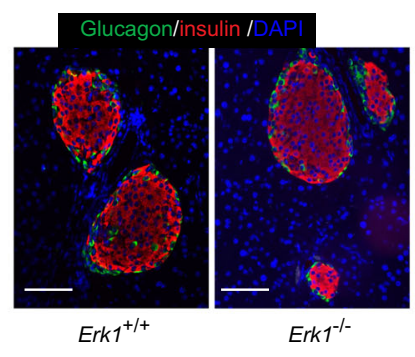

h

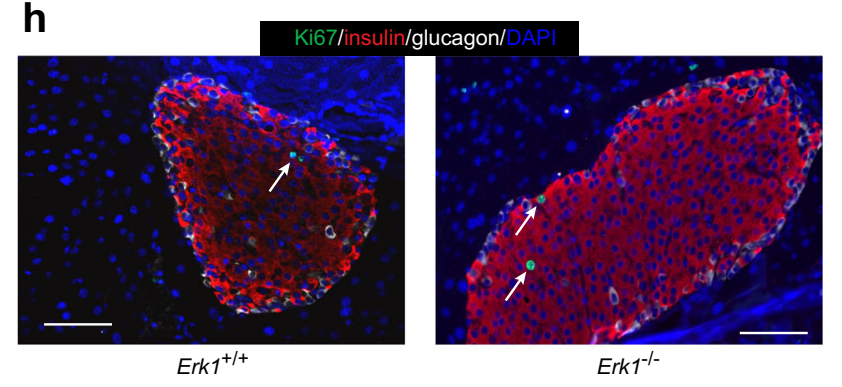

i
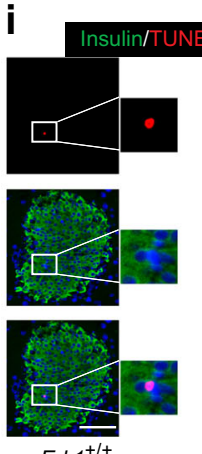

$E r k 1^{+/+}$
C

d
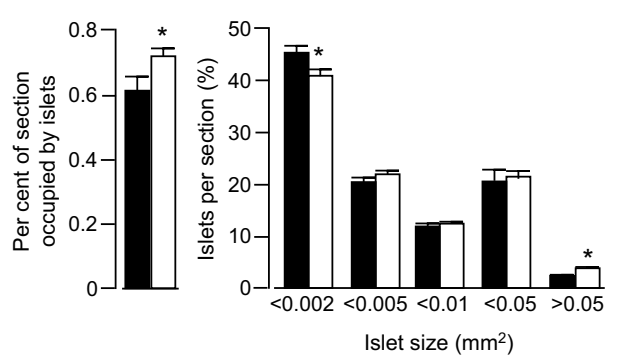

g

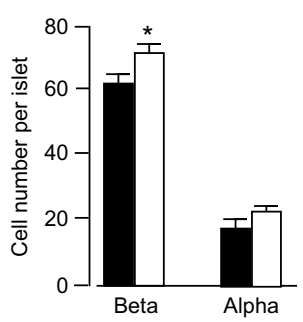

$2.24 \pm 0.40 \mathrm{~g} / 100 \mathrm{~g}$ body weight in $E r k l^{-/-}$mice; $p<0.05$; $n=9$ ). Altogether, these results reveal a new role of ERK1 in aged pancreatic beta cells, showing that it adversely affects islet integrity in aged mice.

\section{Discussion}

In this study, we aimed to determine whether ERK1 and ERK2 have a specific role in mouse beta cells. We report that ERK1 and ERK2 are equally expressed and that the lack of ERK1 was not compensated for by an upregulation (expression and activation) or relocation of ERK2. Moreover, we reveal a crucial role for ERK1 in glucoseinduced MSK1, p90RSK and CREB activation in mouse pancreatic islets since ERK2 was unable to fully compensate for the lack of ERK1. Furthermore, because MSK1 and CREB activity was restored when ERK1 was reintroduced in Erk1 $1^{-/}$ mouse beta cells, and not when ERK2 was overexpressed, this indicates a specific role for ERK1.

The expression of Irs 2 was reported to be regulated by CREB [33]. Nevertheless, despite a $65 \%$ reduction in activation of CREB by glucose, Irs 2 gene expression was not affected in Erk1 ${ }^{-1-}$ mouse islets and the islet 
Fig. 8 ERK1 is involved in periinsulitis caused by ageing. (a) Representative microphotographs of H\&E-stained pancreas sections from 10-month-old mice. (b) Islet number (c) per cent of section occupied by islets and (d) islet distribution per pancreatic section. (e) Two non-infiltrated islets (indicated by yellow arrows) and one infiltrated islet (indicated by a white arrow; also in the zoomed image) are shown. (f) Insulin, CD3 and CD8 immunostaining from $\mathrm{Erkl}^{+/+}$ mouse pancreas sections. (g) Percentage of infiltrated islets. Change in blood glucose during (h) i.p. glucose tolerance test and (i) insulin tolerance test. (j) $\left[\mathrm{Ca}^{2+}\right]_{\mathrm{c}}$ and $(\mathbf{k})$ insulin secretion in freshly isolated islets. Scale bars, $100 \mu \mathrm{m}$; data are

means $\pm \mathrm{SEM}$; (a-h) $n=12$ mice, (i) $n=6$ mice or $(\mathbf{j}, \mathbf{k}) n=4$ mice; $* p<0.05$, ** $p<0.01$ and $* * * p<0.001$ compared with Erk ${ }^{+/+}$mouse cells (Student's $t$ test). Thick trace/black bars/black circles, $\mathrm{Erkl}^{+/+}$mice; thin trace/ white bars/white circles, $E r k 1^{-/}$ mice. AOC, area over the curve a

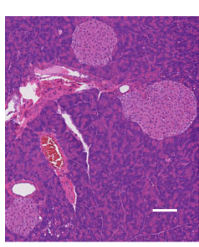

Erk1 ${ }^{+/+}$

e
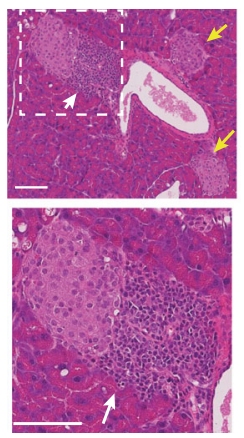

Erk1 $^{+/+}$

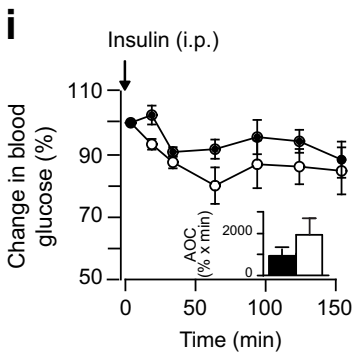

j

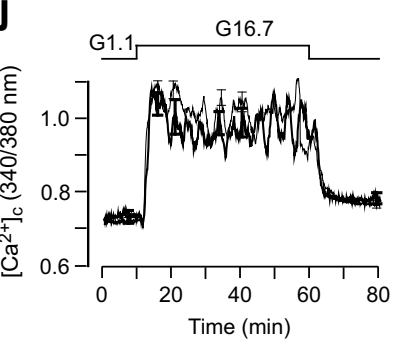

g
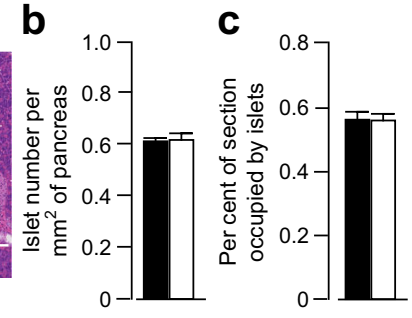

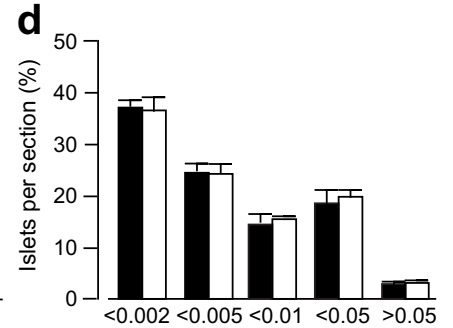

h
Islet size $\left(\mathrm{mm}^{2}\right)$
Insulin/CD3/CD8/
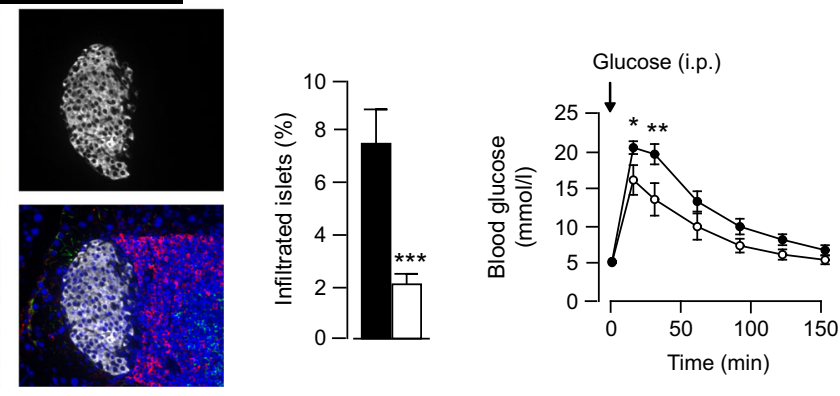

k

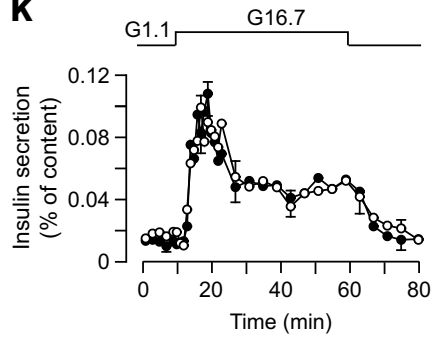

mass was even slightly increased in 4-month-old mice. CREB has been primarily found to be phosphorylated at S133 by protein kinase A (PKA) and, more recently, by MSK1 and p90RSK [14, 31]. It is important to bear in mind that CREB expression was not altered in $E r k 1^{-1}$ mouse islets. Therefore, in vivo, CREB can still be activated by stimuli other than glucose that directly activate PKA, such as glucagon-like peptide-1 [35]. Nevertheless, it has been reported that a beta cell-specific CREB ablation in adult mice did not produce a major phenotype in vivo and did not affect Irs 2 mRNA level or beta cell mass unless the mice/islets were challenged with high-fat diet or with a cocktail of cytokines [36]. ERK1/2 have been shown to be involved in insulin gene expression [5], but ERK1 is not specifically required for insulin gene expression, or at least ERK2 activation seems to be sufficient to compensate for the lack of ERK1.

We have reinvestigated the role of ERK1 and ERK2 in GSIS using three different MEK inhibitors and Erk1 ${ }^{-/-}$mice. Although we cannot rule out the possibility that another protein kinase was also targeted by MEK inhibitors, our study and those of others $[12,26]$ point to the necessity of carefully investigating whether MEK inhibitors affect changes in metabolism and $\left[\mathrm{Ca}^{2+}\right]_{\mathrm{c}}$ before drawing any conclusions about ERK1/2 signalling pathways. We showed that ERK1 activation and recruitment underneath the plasma membrane only accounts for $25 \%$ of the ERK1/2 activation. We have not investigated whether a knockdown of ERK2 expression was sufficient to decrease the first phase of insulin secretion but we report that ERK2 activity is likely sufficient for its full regulation. As possible targets for regulating insulin secretion, focal adhesion kinase (FAK) and paxillin [37] and Rac1 [7] have been proposed in clonal beta cells. Interestingly, a specific activation of paxillin by ERK2 (and not ERK1) was shown in the lungs [38]. Although ERK1 is actively recruited beneath the plasma membrane by glucose, ERK1 seems dispensable for the regulation of insulin secretion. Synapsin $\mathrm{I}$, which is not involved in the regulation of insulin secretion [39, 40], has been proposed to be a target of ERK1/2 [8]. Interestingly, Synapsin I seems to co-localise with small vesicles such as synaptic-like microvesicles [40], the release of which is regulated by glucose $[41,42]$. The mechanisms leading to ERK1/2 translocation to the plasma membrane are unknown. Different scaffold proteins target ERK1/2 to specific sites [43], such as Sefl for Golgi/endoplasmic reticulum or 
MEK partner 1 (MP-1) for endosomes. The specific anchors at the plasma membrane are kinase suppressor of Ras (KSR)1/2 (in cholesterol-rich domains) and paxillin (in focal adhesion), which are both expressed in beta cells [44].

Beta cell functions are altered in aged animals [45]. We observed that the natural process of ageing was associated with the development of a moderate pancreatic inflammation, which was less severe than in NOD mice [46] since it concerned only $\sim 7 \%$ of the islets and our mice never developed diabetes. Similar peri-insulitis has been reported by others in aged C57BL/6 J mice [47]. Most importantly, $\mathrm{CD}^{+} \mathrm{T}$ cells and macrophages were also reported in peri-islet regions of aged control human pancreases [48]. This peri-insulitis was significantly decreased in $E r k 1^{-1-}$ mice. Since we have used a global knockout, we think that this reduced peri-insulitis is not specific to beta cells. Indeed, obese leptin-deficient mice lacking ERK1 (ob/ob-Erk1 $\left.1^{-/}\right)$display reduced expression of mRNA encoding inflammatory cytokines and T lymphocyte markers in the adipose tissue [23]. Additionally, ERK1 is involved in thymocyte maturation [19], and both ERK1 and ERK2 are involved in the process of positive selection and affect $\mathrm{CD}^{+}$and $\mathrm{CD} 8^{+}$T cell maturation [49] and macrophage development [50]. The reason why aged $\mathrm{Erkl}^{-1-}$ mice showed better glucose tolerance is unclear but is certainly caused by a combination of several factors, such as a reduced pancreatic inflammation and the tendency of both plasma insulin concentration and insulin sensitivity to be increased.

In conclusion, ERK1 is necessary for glucose-induced full activation of key proteins involved in beta cell survival. Nevertheless, as shown by the absence of a clear-cut phenotype in $\mathrm{Erkl}^{-/-}$mice, ERK1 is dispensable in normal conditions in living mice. ERK1 has been shown to be involved in the development of insulin resistance [20] and its role in beta cells indicates that dysregulation of ERK1 activity could play a role in the progression of type 2 diabetes. By contrast, ERK2 activity is likely sufficient for insulin gene expression and the first phase of GSIS. Future studies are required to identify the targets involved. The phenotypic differences observed between ERK1 and ERK2 could reside either in differential substrate specificity or differences in ERK intensity signal. The existence of a viable Erk2 $2^{-/-}$transgenic mouse that overexpresses ERK1 to compensate for the absence of ERK2 [16] should help to determine whether ERK2 is specifically required for the first phase of GSIS and insulin gene expression, or whether it is the global ERK activity that is necessary.

Acknowledgements The authors thank L. Ruiz (Institut de Génomique Fonctionnelle, France) and RHEM and MRI facilities (Montpellier, France) for technical assistance, Q. Durrix and E. Gavois (Institut de Génomique Fonctionnelle, France) for technical assistance with animals, C. Jopling (Institut de Génomique Fonctionnelle, France) for editorial assistance and C. Reynes (Faculté des sciences pharmaceutiques et biologiques, Montpellier, France) for statistical assistance.
Data availability The datasets generated during and/or analysed during the current study are available from the corresponding author on reasonable request.

Funding This work was supported by the Centre National de la Recherche Scientifique, Institut National de la Santé et de la Recherche Médicale, Fondation pour la Recherche Médicale (grant DRM20101220453) and research allocation from SFD-ALFEDIAM.

Duality of interest The authors declare that there is no duality of interest associated with this manuscript.

Contribution statement ML, JR, SC, DM, VC, JM, AV and GB researched data, contributed to analysis and discussions of data and revised the manuscript. GP and JP provided the mice, contributed to analysis and discussion of data and revised the manuscript. J-FT and SD contributed to analysis and discussion of data and revised the manuscript. MAR contributed to the conception and design of the study, the acquisition, analysis and interpretation of data and to drafting/revising the manuscript, and is the guarantor of this work. All authors approved the final version to be published.

\section{References}

1. Weir GC, Bonner-Weir S (2013) Islet beta cell mass in diabetes and how it relates to function, birth, and death. Ann N Y Acad Sci 1281: 92-105

2. Henquin JC (2011) The dual control of insulin secretion by glucose involves triggering and amplifying pathways in $\beta$-cells. Diabetes Res Clin Pract 93(Suppl 1):S27-S31

3. Gilon P, Chae HY, Rutter GA, Ravier MA (2014) Calcium signaling in pancreatic $\beta$-cells in health and in type 2 diabetes. Cell Calcium 56:340-361

4. Eliasson L, Abdulkader F, Braun M et al (2008) Novel aspects of the molecular mechanisms controlling insulin secretion. J Physiol 586:3313-3324

5. Lawrence M, Shao C, Duan L, McGlynn K, Cobb MH (2008) The protein kinases ERK1/2 and their roles in pancreatic beta cells. Acta Physiol (Oxf) 192:11-17

6. Briaud I, Lingohr MK, Dickson LM, Wrede CE, Rhodes CJ (2003) Differential activation mechanisms of Erk-1/2 and p70(S6K) by glucose in pancreatic $\beta$-cells. Diabetes 52:974-983

7. Kowluru A, Veluthakal R, Rhodes CJ et al (2010) Protein farnesylation-dependent Raf/extracellular signal-related kinase signaling links to cytoskeletal remodeling to facilitate glucose-induced insulin secretion in pancreatic $\beta$-cells. Diabetes 59:967-977

8. Longuet C, Broca C, Costes $\mathrm{S}$ et al (2005) Extracellularly regulated kinases 1/2 (p44/42 mitogen-activated protein kinases) phosphorylate synapsin I and regulate insulin secretion in the MIN6 $\beta$-cell line and islets of Langerhans. Endocrinology 146:643-654

9. Tomas A, Yermen B, Min L, Pessin JE, Halban PA (2006) Regulation of pancreatic $\beta$-cell insulin secretion by actin cytoskeleton remodelling: role of gelsolin and cooperation with the MAPK signalling pathway. J Cell Sci 119:2156-2167

10. Bowe JE, Chander A, Liu B, Persaud SJ, Jones PM (2013) The permissive effects of glucose on receptor-operated potentiation of insulin secretion from mouse islets: a role for ERK1/2 activation and cytoskeletal remodelling. Diabetologia 56:783-791

11. Benes C, Roisin MP, Van Tan H et al (1998) Rapid activation and nuclear translocation of mitogen-activated protein kinases in response to physiological concentration of glucose in the MIN6 pancreatic beta cell line. J Biol Chem 273:15507-15513 
12. Wauson EM, Guerra ML, Barylko B, Albanesi JP, Cobb MH (2013) Off-target effects of MEK inhibitors. Biochemistry 52:5164-5166

13. Yoon S, Seger R (2006) The extracellular signal-regulated kinase: multiple substrates regulate diverse cellular functions. Growth Factors 24:21-44

14. Cargnello M, Roux PP (2011) Activation and function of the MAPKs and their substrates, the MAPK-activated protein kinases. Microbiol Mol Biol Rev 75:50-83

15. Busca R, Christen R, Lovern M et al (2015) ERK1 and ERK2 present functional redundancy in tetrapods despite higher evolution rate of ERK1. BMC Evol Biol 15:179

16. Fremin C, Saba-El-Leil MK, Levesque K, Ang SL, Meloche S (2015) Functional redundancy of ERK1 and ERK2 MAP kinases during development. Cell Rep 12:913-921

17. Imamura O, Pages G, Pouyssegur J, Endo S, Takishima K (2010) ERK1 and ERK2 are required for radial glial maintenance and cortical lamination. Genes Cells 15:1072-1088

18. Saba-El-Leil MK, Vella FD, Vernay B et al (2003) An essential function of the mitogen-activated protein kinase ERK2 in mouse trophoblast development. EMBO Rep 4:964-968

19. Pages G, Guerin S, Grall D et al (1999) Defective thymocyte maturation in p44 MAP kinase (ERK1) knockout mice. Science 286: 1374-1377

20. Bost F, Aouadi M, Caron L et al (2005) The extracellular signalregulated kinase isoform ERK1 is specifically required for in vitro and in vivo adipogenesis. Diabetes 54:402-411

21. Boulton TG, Nye SH, Robbins DJ et al (1991) ERKs: a family of protein-serine/threonine kinases that are activated and tyrosine phosphorylated in response to insulin and NGF. Cell 65:663-675

22. Costes S, Broca C, Bertrand G et al (2006) ERK1/2 control phosphorylation and protein level of cAMP-responsive element-binding protein: a key role in glucose-mediated pancreatic $\beta$-cell survival. Diabetes 55:2220-2230

23. Jager J, Corcelle V, Gremeaux T et al (2011) Deficiency in the extracellular signal-regulated kinase 1 (ERK1) protects leptindeficient mice from insulin resistance without affecting obesity. Diabetologia 54:180-189

24. Kanda Y, Shimoda M, Tawaramoto K et al (2009) Molecular analysis of $\mathrm{db}$ gene-related pancreatic beta cell dysfunction; evidence for a compensatory mechanism inhibiting development of diabetes in the db gene heterozygote. Endocr J 56:997-1008

25. Satoh Y, Endo S, Nakata T et al (2011) ERK2 contributes to the control of social behaviors in mice. J Neurosci 31:11953-11967

26. Ripple MO, Kim N, Springett R (2013) Acute mitochondrial inhibition by mitogen-activated protein kinase/extracellular signalregulated kinase (MEK) 1/2 inhibitors regulates proliferation. J Biol Chem 288:2933-2940

27. Yamaguchi T, Kakefuda R, Tajima N, Sowa Y, Sakai T (2011) Antitumor activities of JTP-74057 (GSK1120212), a novel MEK1/2 inhibitor, on colorectal cancer cell lines in vitro and in vivo. Int J Oncol 39:23-31

28. Bain J, Plater L, Elliott M et al (2007) The selectivity of protein kinase inhibitors: a further update. Biochem J 408:297-315

29. Harvey CD, Ehrhardt AG, Cellurale C et al (2008) A genetically encoded fluorescent sensor of ERK activity. Proc Natl Acad Sci U S A 105:19264-19269

30. Ravier MA, Tsuboi T, Rutter GA (2008) Imaging a target of $\mathrm{Ca}^{2+}$ signalling: dense core granule exocytosis viewed by total internal reflection fluorescence microscopy. Methods 46:233-238

31. Arthur JS, Cohen P (2000) MSK1 is required for CREB phosphorylation in response to mitogens in mouse embryonic stem cells. FEBS Lett 482:44-48
32. Diraison F, Parton L, Ferre P et al (2004) Over-expression of sterolregulatory-element-binding protein-1c (SREBP1c) in rat pancreatic islets induces lipogenesis and decreases glucose-stimulated insulin release: modulation by 5 -aminoimidazole-4-carboxamide ribonucleoside (AICAR). Biochem J 378:769-778

33. Jhala US, Canettieri G, Screaton RA et al (2003) cAMP promotes pancreatic $\beta$-cell survival via CREB-mediated induction of IRS2. Genes Dev 17:1575-1580

34. Jambal P, Masterson S, Nesterova A et al (2003) Cytokinemediated down-regulation of the transcription factor cAMPresponse element-binding protein in pancreatic $\beta$-cells. J Biol Chem 278:23055-23065

35. Dalle S, Longuet C, Costes S et al (2004) Glucagon promotes cAMP-response element-binding protein phosphorylation via activation of ERK1/2 in MIN6 cell line and isolated islets of Langerhans. J Biol Chem 279:20345-20355

36. Shin S, Le Lay J, Everett LJ et al (2014) CREB mediates the insulinotropic and anti-apoptotic effects of GLP-1 signaling in adult mouse $\beta$-cells. Mol Metab 3:803-812

37. Rondas D, Tomas A, Halban PA (2011) Focal adhesion remodeling is crucial for glucose-stimulated insulin secretion and involves activation of focal adhesion kinase and paxillin. Diabetes 60:1146 1157

38. Radtke S, Milanovic M, Rosse C et al (2013) ERK2 but not ERK1 mediates HGF-induced motility in non-small cell lung carcinoma cell lines. J Cell Sci 126:2381-2391

39. Wendt A, Speidel D, Danielsson A et al (2012) Synapsins I and II are not required for insulin secretion from mouse pancreatic $\beta$-cells. Endocrinology 153:2112-2119

40. Krueger KA, Ings EI, Brun AM, Landt M, Easom RA (1999) Sitespecific phosphorylation of synapsin I by $\mathrm{Ca}^{2+} /$ calmodulin-dependent protein kinase II in pancreatic betaTC 3 cells: synapsin I is not associated with insulin secretory granules. Diabetes 48:499-506

41. MacDonald PE, Obermuller S, Vikman J et al (2005) Regulated exocytosis and kiss-and-run of synaptic-like microvesicles in INS1 and primary rat $\beta$-cells. Diabetes 54:736-743

42. Bergeron A, Pucci L, Bezzi P, Regazzi R (2014) Analysis of synaptic-like microvesicle exocytosis of $\beta$-cells using a live imaging technique. PLoS One 9:e87758

43. Roskoski R Jr (2012) MEK1/2 dual-specificity protein kinases: structure and regulation. Biochem Biophys Res Commun 417:5-10

44. Benner C, van der Meulen T, Caceres E et al (2014) The transcriptional landscape of mouse beta cells compared to human beta cells reveals notable species differences in long non-coding RNA and protein-coding gene expression. BMC Genomics 15:620

45. Barker CJ, Li L, Kohler M, Berggren PO (2015) Beta-cell $\mathrm{Ca}^{2+}$ dynamics and function are compromised in aging. Adv Biol Regul 57:112-119

46. Atkinson MA, Leiter EH (1999) The NOD mouse model of type 1 diabetes: as good as it gets? Nat Med 5:601-604

47. Omar BA, Vikman J, Winzell MS et al (2013) Enhanced beta cell function and anti-inflammatory effect after chronic treatment with the dipeptidyl peptidase-4 inhibitor vildagliptin in an advancedaged diet-induced obesity mouse model. Diabetologia 56:17521760

48. Ehses JA, Perren A, Eppler E et al (2007) Increased number of isletassociated macrophages in type 2 diabetes. Diabetes 56:2356-2370

49. Fischer AM, Katayama CD, Pages G, Pouyssegur J, Hedrick SM (2005) The role of ERK1 and ERK2 in multiple stages of T cell development. Immunity 23:431-443

50. Richardson ET, Shukla S, Nagy N et al (2015) ERK signaling is essential for macrophage development. PLoS One 10: e0140064 